\title{
The gēr [immigrant] in postexilic prophetic eschatology: The perspectives of Ezekiel 47:22-23 and Malachi 3:5
}

\author{
Author: \\ Bob Wielenga ${ }^{1}$ (1) \\ Affiliation: \\ ${ }^{1}$ Unit of Reformational \\ Theology, Faculty of \\ Theology, North-West \\ University, Potchefstroom, \\ South Africa \\ Corresponding author: \\ Bob Wielenga, \\ bwielenga@outlook.com \\ Dates: \\ Received: 11 Mar. 2020 \\ Accepted: 19 May 2020 \\ Published: 25 Aug. 2020 \\ How to cite this article: \\ Wielenga, B., 2020, 'The gêr \\ [immigrant] in postexilic \\ prophetic eschatology: \\ The perspectives of Ezekiel \\ 47:22-23 and Malachi 3:5', \\ In die Skriflig 54(1), a2617. \\ https://doi.org/10.4102/ids. \\ v54i1.2617

\section{Copyright:} \\ (c) 2020. The Authors. \\ Licensee: AOSIS. This work \\ is licensed under the \\ Creative Commons \\ Attribution License.
}

In this article the relationship between Ezekiel 47:22-23 and Malachi 3:5, on the topic of the status of the immigrant in postexilic Judaism, is examined. The research has two focal points: the prophetic eschatological context of both prophetic pronouncements and the normative impact of the Law of Moses on both, although the first is guided by the 'Holiness Code' and the last by the 'Deuteronomic Code'. This requires a discussion of the relationship between both 'codes' and an evaluation of their teaching on the status of the immigrant. This is followed by an examination of the literary and theological context in which the immigrant appears in both the texts examined. This article contends that Malachi 3:5, denoting the present time in prophetic eschatology, should be read against the background of Ezekiel 47:22-23, denoting the future time in prophetic eschatology. Compliance with the Law of Moses is in both cases a covenantal obligation anchored in the redemptive past.

Keywords: Immigrant ( $g \bar{e} r)$; Holiness Code; Deuteronomic Code; Theological reading of Ezekiel 47:22-23 and Malachi 3:5; Prophetic eschatology.

\section{Introduction}

In the postexilic prophetic literature, the gèr occurs only in Zechariah 7:10 and Malachi 3:5, bracketed together with the orphan and the widow as in pre-exilic literature (see Awabdy 2011; Bosman 2018; Carroll 2013; Friedl 2016; Gowan 1987; Onishi 2017; Van Houten 1992; 2012; Wünsch 2014; Zehnder 2017). Some relate this limited number to the postexilic ethnic exclusivity as found in Ezra-Nehemiah. This did not create a welcoming climate for people coming from outside to settle in the closely-knit, small community of native-born Jews, who had just returned from exile, fighting to survive the dire circumstances of Persian Yehud (Brett 1996:11; Smith-Christopher 1996:124). ${ }^{1}$ Whatever the reason for this exclusivity, the gèr appears in prophecies that shape the eschatological future of the Jewish community in the postexilic era.

This article contends that an explanation for the appearance of the $g \bar{e} r^{2}$ in Malachi 3:5 could be found in Ezekiel's eschatological vision for postexilic Israel in Ezekiel 40-48. The gè r is explicitly mentioned in Ezekiel 47:22-23. Both texts function in the prophetic eschatological discourse in postexilic Yehud, but the question is how they are connected and why.

In view of the reference in Malachi 3:22 to the Law of Moses (Wielenga 2019:2-8), the question arises how its teachings could have influenced Malachi 3:5 on the issue of the geer. In Ezekiel 47:22-23, the influence of the Law of Moses can be pointed out as well. However, a different 'law code' is employed in Ezekiel 47, namely the Holiness Code (HC), Leviticus 17-26 $6^{3}$ and in Malachi 3 it is mostly Deuteronomy 12-26 - The Deuteronomic Code (DC). ${ }^{4}$ This requires a short review of the relationship between these two 'law $\operatorname{codes}^{\prime 5}$ concerning their specific position on the $g \bar{e} r$. This

1.A socio-anthropological and socio-psychological approach to the exilic-postexilic context is advocated here (see Rom-Shilon 2005:1-45), rather than a theological one, followed in this article (Wielenga 2013). Awabdy (2012:258, 266-268) points out that ethnicity does not play a role in Israel's legislation concerning the immigrants among them, different from the contemporary ancient Near Eastern praxis.

2.For the widow (and orphan), left out in this investigation, see Heller (2007) and Friedl (2016:190-191). See Na'adav (2008:276-278) for theories about the composition of the triangle (plus Levite a quadrangle), orphan, widow and sojourner (immigrant).

3.See Bergsma (2015) for the direction of influence between HC and Ezekiel. Re the question which Code influenced Ezekiel, it should be considered that only the HC-influence on Ezekiel re the immigrant is under discussion here. Gile (2013:287, 290-296, 300), for instance focuses on Ezekiel's theology of exile in his argument for influence of HC and Deuteronomy $(4 ; 29-31)$ both on Ezekiel. These positions are not mutually exclusive.

4. DC = Deuteronomic Code (Dt 12-26), and HC = Holiness Code (Lv 17-26). CC, the Covenant Code (Ex 20:22-23:19), is not included in this investigation. P = Priestly Code (here only Lv 1-16), will be included where needed. See Schwartz (2009:1-12) for a discussion about the relationship between $\mathrm{P}$ and $\mathrm{HC}$.

5.See Wielenga (2019:3) for the character of the 'law codes' with reference to Braulik (2012:555-557): they do not comprise enforceable legislation, but rather covenantal instructions people felt compelled to observe. Theologically the 'law codes' are not 'law', but 'gospel'. Hence the quotation marks around 'law codes'. 
will be done in the first section preceding the one dealing with the specific teachings of these 'law codes' about the gèr. This will be followed by an investigation in Ezekiel 47:22-23 in the context of Ezekiel 38-39 and 40-48. The last section will deal with the function of the gēr-reference in Malachi's eschatology. ${ }^{6}$

\section{The gēr in the Old Testament (Hebrew Bible)}

In some Bible translations, the term gêr is rendered as 'resident alien' or 'sojourner'. In this article, it is translated as 'immigrant', conforming to the modern praxis to call people 'immigrants' who have attained a permanent resident status in the land where they were not born (Hartshorn 2010:1-5; Oommen 1997). In contrast to other terms for foreigner in the Old Testament (OT) (like toshab, nokri, zar [see Awabdy 2012; Burnside 2001:12-19; Wünsch 2014:1138-1144]), only the $g \bar{e} r$ is described as a resident with permanent status in Israel, having been forced to leave his own country to settle in Israel by the usual disasters such as war, drought and famine. He had not yet full citizen's rights, among which the lack of land and property rights impacted his position most severely. Therefore, lacking the protection and support from the natural social networks like family, clan or tribe, he belonged to the class of vulnerable inhabitants of the land (together with the orphan and the widow). Some restrictions were placed upon his participation in Israel's religious life (Wünsch 2014:1144-1147). Nevertheless, he was just like the native-born, required to observe the teachings of the Law of Moses. In contrast with the nokri or the toshab, the ger should be received as a fully-fledged member of society.

\section{The relationship between the 'Holiness Code' and the 'Deuteronomic Code'}

To understand the immigrant's position in Israel according to the two different 'law codes', this article posits that the narrated time, assumed in the historical texts of the Pentateuch (Awabdy 2012:39-40; Wünsch 2014:1134), best explains their differences and similarities. The 'law codes' were accessible in the postexilic era to the people in the authoritative 'book' of the Law of Moses that Ezra brought with him to Jerusalem from Persia (Ezr 6:18; 7:14; Neh 8:1, 14; Wielenga 2013:3-4). ${ }^{7}$ It is then plausible that the 'law codes' were read from a postexilic perspective and understood accordingly, minimising the significance of their differences when implementing the directives concerning the immigrant in the new historical situation.

6.See the insight of Wielenga (1994:224-235; $2015: 2 ; 2016: 1 ; 2018: 1$ ) for the methodology employed in this article.

7.See Schniedewind (2015:305-321) about the scripturalising of texts as source of their authority.
Typically, the 'law codes' in the OT occur within a narrative context. As Wright (2006) formulates it:

The narrative expresses the indicative. Here is what has happened in your history, and these are the things that $\mathrm{YHWH}$ your God has done. Then the law expresses the responsive imperative. Now then, this is how you must behave in the light of such facts. (p. 59)

The 'law codes' are related to the stages of the narrated history in which they were promulgated. This is at least partly, an explanation for the differences between them that remained unharmonised in the final text (Wünsch 2014:1133). Hence, it is plausible to read DC as an update of HC (Zehnder 2017:198, 230-231), having been originated from different historical contexts with their own perspectives. The one 'code' was not devalued at the cost of the other; both were rather considered to be complementary. The history, narrated in the Pentateuch, suggests that HC was pronounced at an earlier stage than the DC. ${ }^{8}$

In the Pentateuchal narrative, $\mathrm{HC}$ was given by God through Moses during Israel's time at Mount Horeb to make viable the dwelling of the holy God among sinful Israel (Ex 25; 32-34) in the promised land. The focus of HC is on God's holy presence among the people, with consequences for the purity of the land and the sanctification of its inhabitants (Awabdy 2011:38-39; Bosman 2018:572; Joosten 1996:132-135). The emphasis is on the distinctness of Israel's way of life from that of the other nations ( $\operatorname{Lv} 18: 2-3 ; 19: 2)$, because Israel's God was incomparably distinct from the gods of these nations. Their quality of life should reflect the character of the Lord, the Holy One (Lv 18-20). Holiness was not only ritually but also ethically conceived. The position of the immigrant in Israel is addressed in HC to enhance God's holiness and Israel's reflection of it in their daily life from Mount Horeb onwards.

At the border of the promised land, DC is given by Moses 'according to all that Yahweh commanded him' (Dt 1:1-3). The narrative stresses that this 'code' was written down, and placed next to the ark of the covenant (Dt 31:24-26) to be used in the teaching ministry of the priests inside the promised land (Dt 10:5, 8; 30:10; 31:9-13). ${ }^{9}$ DC focuses on the holiness of the people in the promised land, where they should develop a God-pleasing society that would attract the nations to Israel and so to God (Dt 4:5-8; 28:9-10)..$^{10}$ The precise instructions about the organisation of society from Deuteronomy 14 onwards, are preceded in Deuteronomy 12 by God's directive to Israel to participate in worship at the place chosen by God, as the condition for his blessing their efforts to develop the envisaged society. In this context, DC deals with the position of the immigrant from a perspective different from, but not in conflict with HC. ${ }^{11}$

8.This position differs from the usual one (see Bosman 2018:572, Hieke 2015:78 and Van Houten 1992), and is rather based on a synchronic approach.

9.About Deuteronomy 1:1-5, see Arnold (2017:139-149) in his discussion about the vox or the verba ipsissima Moysi in Deuteronomy.

10.Awabdy (2012:258-270) and Gowan (1987:343) refer to the different ways in which the immigrants were treated in Israel and in the ancient Near East.

11.See McConville (2002:33-45) for the approach to Deuteronomy followed in this article. 
Against this background, this article tries to understand how both 'codes' in conjunction have impacted the eschatological discourse as expressed in Ezekiel 47:22-23 and Malachi 3:5. As will be shown, the narrative of redemptive history (the Egypt-experience) is effectively used by the prophets as a 'powerful motive for practicing social justice' (Wright 2006:449). The origin of the 'law codes' as well as their implementation are embedded in the narrated history of redemption and its consequences.

\section{The position of the immigrant in the 'Holiness Code' and the 'Deuteronomic Code'}

\section{The relevant texts in Leviticus 17-26}

Exodus 12:38 mentions 'a mixed multitude' (NASB) leaving Egypt with Israel (Onishi 2017:38). Right from the start, Israel had to accommodate these fellow travellers within its religious and social space. ${ }^{12}$ Right from the beginning, the Lord already taught Israel through HC how to behave towards these travellers during their journey to and their stay in the promised land. The following examples should suffice to understand the nature of $\mathrm{HC}^{\prime}$ 's teachings.

In Leviticus 17:8-15, the immigrant is included among those who handle sacrifices and blood of animals as prescribed by God (Lv 17:11; see also 22:17-25). He, too, should abstain from sexual immorality ( $\mathrm{Lv} 18: 6-23 ; 20: 10-21)$. The contrast with the nations, dispossessed of the promised land and 'vomited out' with their detestable practices (Lv 18:3, 24-28), is strongly emphasised. Israel had to reflect the holiness of God who dwelled among them. The immigrant too was obliged to reject these 'detestable' practices and should disown them if they formed part of his own cultural inheritance. The assumption here is certainly a far-reaching form of integration of the immigrant in the Israelite community, that in the postexilic era must have been accepted as authorised by the Law of Moses, facilitating his full assimilation as proselyte.

This integration is even more clearly expounded in Leviticus 19:33-34, which is connected with 19:14 (the care for the disabled) and with 19:32 (the support for the elderly) by the concluding expression, 'I am the Lord' (Tidball 2005:244). Observance of the directive to love the immigrant as yourself, despite his ethnic descent, meant to include him in the social care system that Israel had to develop in the promised land. In Leviticus 19:5-10 an example is given (Tidball 2005:237): the immigrant should be included in the sharing of food, be it at the meal of the fellowship offering ( $\operatorname{Lv} 7: 11-15)$ or in the gleaning of the fields at harvest time ( $\operatorname{Lv} 19: 9-10)$. The focus is, however, on God whose holiness should be reflected in ethical purity in a society focused on the vulnerable classesthe immigrant included. Extra attention is given to the immigrant by evoking the memory of Israel's redemption as 12.In Numbers $12: 1$ mention is made of Moses' Cushite wife, plausibly a member of this crowd (Adamo 2019:3-4). immigrants from Egypt (Onishi 2017:55-56). This should prompt the native-born to include the immigrant in their community on equal grounds. ${ }^{13}$

The Jubilee legislation seems to differentiate more distinctly in Leviticus 25:47 between the position of the immigrant and that of the native-born, than one would have expected based upon Leviticus 19, for instance a reason for some to ascribe to Leviticus 19 a pre-exilic and to Leviticus 25 a postexilic date (Van Houten 1992:235-236). Whether this postexilic date is historically plausible or not, the Mosaic provenance of this directive was not under discussion in postexilic times. One should first look for reasons for the apparently unequal treatment of native-born Israelites and immigrants in the Jubilee legislation in pre-exilic times.

Leviticus 25:23 looks like a good starting point (Jokiranta 2014:661), where the land-issue is settled once and for all. The land is mine, says the Lord; as the Lord's tenants, the Israelites were not owners of the land; it was allotted to them by God (Jos 15-22) for a purpose (Gn 12:3). As divine Owner of the land, God had his own redemptive plan with his land with which its inhabitants had to comply (Wright 2006:292). In this context, the position of the immigrant was protected but should not be exploited by him to the detriment of the nativeborn, God's chosen people. The issue is not so much that an immigrant would become rich, but that he would take advantage of the misfortune of the native-born (debt slavery) who had welcomed him in their midst. In a land with its holy Owner present, rampant poverty, social inequality and illtreatment of the socially vulnerable, be they native-born or immigrant, would reflect badly on his character and it would make them impure. The focus in Leviticus 25:47 is on the holiness of the Owner and his land, and that should be the concern of its inhabitants, both native-born and immigrant (Joosten 1996:125-132). ${ }^{14}$

\section{The relevant texts in Deuteronomy 12-26}

One could divide the legislation of Deuteronomy concerning the immigrant into several categories, covering all aspects of social and religious life as envisioned in the narrative of Moses and written down by him in DC. This starts with instructions about worship, followed by poverty relief and the legal status of and labour policy regarding the immigrant (Awabdy 2012:60-91; Carroll 2013:447-450). However, the covenantal basis for the DC immigration laws should be investigated first.

Burnside (2001:3-5), Friedl (2016:181) and Wünsch (2014:1 136) correctly point out that the immigrant laws too presuppose the Shema in Deuteronomy 6:4-6 as precondition

13.See Onishi (2017:55-77) about the different functions of the two motivation clauses in the 'law codes': 'you were slaves in Egypt' (Dt 5:14-15; 16:12; 24:17-18, etc.) is a warning not to ill-treat immigrants: 'you were immigrants in Egypt' (Lv 19:34), positively prompted Israel to treat immigrants equally as part of their holy life in the land.

14.There is not enough evidence in the OT that this law was ever observed before or after the exile. However, in postexilic Yehud, this perspective on social justice and after the exile. However, in postexilic Yehud, this perspective on social justice and
equality (see e.g. Is 61:1-2) must have been accepted as part of the authoritative 'book' of the Law of Moses (Wielenga 2013). 
for a successful integration process of the immigrant in the Israelite society (Dt 26:1-11). The covenantal love for God (áhab) ${ }^{15}$ should motivate the people to show compassion not only for the native-born, but for the immigrant as well with whose position they were familiar due to their experiences in Egypt (Dt 10:12, 18-19). This basic confession of faith had to be foundational throughout Israel's history in the promised land; hence, the emphasis on the teaching ministry at home and in the temple needed to keep the Shema alive in their communal and personal memory.

This teaching ministry (Wielenga 2019:2-3) should have an impact on the observance of the immigration laws as well. They should be remembered and observed from generation to generation (Dt 6:7-10; 11:18-21;31:10-13). It is relevant to bear in mind that the communal teaching ministry took place especially during the great festivals celebrated at the place chosen by God (Dt 12:1-5), in which the immigrants were also allowed to take part. Native-born and immigrant together were confronted with the same instruction in the Law of Moses on how to 'fear the Lord and to walk in obedience to Him' (Dt 12:12).

The question arises how to characterise DC's societal vision for the promised land. Is it an ideological perspective foreign to the reality on the ground after settlement in the land, originating in a completely different historical situation (2 Ki 22-23)? ${ }^{16}$ Or is it intended to be a model ('decrees and laws') that should be observed carefully, 'for this will show your wisdom and understanding to the nations' (Dt 4:5)? This article understands DC to be about the implementation of a theocratic model, in which politics and religion are one, based upon the covenantal relationship between God and his people (McConville 2002:43-44). The fact that sacral and secular laws are collocated in the Pentateuchal 'law codes', supports this contention. DC was meant to be implemented in God's land to create a contrastive society (Dt 12:1-4), intended to attract the neighbouring nations to God (Dt 4:5-8; 28:9-10).

It is with good reason that DC starts in Deuteronomy 12 with 'the laws and decrees' about worship, giving direction to all what subsequently follows (Wielenga 2019:5-7). The absence of any identification of the place chosen by God for worship, fits the historical timeline of the narrative. ${ }^{17}$ That the place must be chosen by God receives, however, full attention (Dt 12:5, 11, 14, 18, 21, 26) as well as the antithetical nature of the worship taking place there, which should have consequences for the sanctification of all areas of life (Arnold 2016:165; Cook 2013:124; Wielenga 2019:6-7).

Worship at the chosen place, where the Lord as the only Owner of the land was actually present (Dt 12:7,12,18), was

15.See Arnold (2011:560-561) for the unity between the affectionate and the cognitive components of covenantal love (cf. also Wielenga 2019:6).

16. Halpern (2013:183) calls DC 'a constitution', limiting the power of the executive (king), ensuring independence of the cult and sequestering the judiciary in response to the cultural flux in 7 th century $\mathrm{BCE}$.

17.For the ongoing extensive scholarly debate about the Weinfeld thesis re centralisation of the cult and its secularising and demythologising effects, see Arnold (2014:236-248; 2016:175) and Vogt (2003:42-46, 67-95). conceived mainly as a family event (Dt 12:7) in which, among other socially vulnerable people, the immigrant was also invited to participate, living as he did 'at the gate' of a household (Awabdy 2012:51-52). ${ }^{18}$ Apart from the Passover (Ex 12:48-49; Dt 16:1-8), he was invited to the Festival of the Weeks (Dt 16:11) and the Festival of the Booths (Dt 16:14), communal feasts celebrated in God's chosen place. In Deuteronomy 26:1-11, the immigrant shared in the first fruits and tithes brought to the place chosen by God - charity was a fruit of worship (Awabdy 2012:73). Clearly, the immigrant was not excluded from the worship at the chosen place, even if there were some restrictions placed upon his participation dependent on his full assimilation in the community of Israel (circumcise or not) as becomes clear in Deuteronomy 14:21 as well (Awabdy 2012:64-65). ${ }^{19}$

As indicated, poverty relief followed directly from worship as also the triennial tithe (Dt 14:22-29) shows, also used to sustain the immigrant (Dt 26:12). The gleaning right given to him (Dt 24:19-21), pointed to the care the native-born had to give to the immigrant as well (Awabdy 2012:60-61; McConville 2002:363) in accordance with the command to love him as God loves him (Dt 10:18-19).

The directives concerning poverty relief are anchored in the teaching of the fourth commandment about the sabbath rest (Dt 5:13-15). One could call this a piece of labour legislation benefitting the whole of society, including the immigrant living 'at the gate' of the household he was attached to (Carroll 2013:449). This affected the immigrant as a day labourer as well (Na'adav 2008:249). He too had the right to receive his wages before the end of the day (Dt 24:14-15). It points to a thoroughly egalitarian society as the politically downgraded position of the hypothetical king (Dt 17:14-20) also shows (Halpern 2013:168, 170, 175). This requires the impartiality expected from the courts (Dt 1:16-17; 17:8-13), the fairness of judges and town elders, the lowest level of Israel's judicial system (Dt 24:5).

DC has been literarily integrated in the covenantal substructure of Deuteronomy (Vogt 2003:26; see also Cook 2015:201-206; McConville 2002:387). There is not only a deliberate literary but also a definite theological connection between DC and Deuteronomy 27-30. The immigrant appears again in these chapters describing the covenant renewal ceremonies where the people were confronted with blessings and curses attached to the covenant document as was usual in the ancient Near Eastern vassal-treaties (Vogt 2003:25-27). The pronouncement of blessings and curses was not an incidental, but an intentional addition to DC. ${ }^{20}$

18.See Na'adav (2008:279) for the gate as the central place in town for the poor to gather, among which the day labourers and immigrants.

19.Deuteronomy 14:21 concurs with Leviticus 17:15 in that meat of animals found already dead made a native-born ritually unclean. However, Deuteronomy stipulates that the gerr, not being a full integrated member of Israel could eat it. The difference with Leviticus 17 could be the result of a difference in focus between $\mathrm{HC}$ and DC (McConville 2002:250-251).

20.See Schniedewind (2015:316-318) for this use of blessings and curses analogous with ancient Near Eastern vassal treaties, conferring authority to the text they are attached to. 
Devotion to God and observance of the people's covenantal obligations were stimulated in this way.

In this way, the protection of the immigrant was a feature of the covenant renewal ceremonies, to start with the one in the fields of Moab (Dt 26:16-19; 29:1). Among the futility curses (Dt 28:43-44), the immigrant was mentioned in the list of covenantal sanctions. ${ }^{21}$ His position should also be safeguarded in the future, as the covenant renewal ceremony on Mount Ebal (Jos 8:30-35), in which he was allowed to participate (Josh 8:33), shows. His protection was taken care of in the form of a covenant curse (Dt 27:19; McConville 2002:393).

\section{The future of the immigrant in Ezekiel 47:22-23}

The reference to the immigrant in Ezekiel 47:22-23 appears in the last section (47:13-48:35) of Ezekiel 40-48. This section provides an eschatological view on the equal redistribution of the land among the tribes of Israel that returned from the Babylonian exile (Joyce 2005:189). In Ezekiel 40-48 its future is envisioned from a strongly theocentric perspective influenced by (P and) HC. ${ }^{22}$ Hence, Ezekiel $40-48$ opens with the return of God to 'his land' (Lv 25:23) to dwell right in the centre of it in the temple (Ezk 43:1-7), surrounded by priests and Levites. That covers 'the holy portion' of the land that belonged exclusively to the Lord (Ezk 45:1-7; 48:14). Special care is taken to separate this sacred centre of the land from the surrounding profane portions, allotted equally among the tribes (Ezk 48:1-29) in territories located in direct contrast with the pre-exilic set-up. This was done to overcome the ancient rivalry between the southern and northern tribes (Le Roux 1987:132). The building of the wall of partition around the temple needed 63 verses to be described (Ezk 40-41), revealing the importance attached to segregating holy and profane (Ganzel \& Holtz 2014:215, 224; Joyce 2005:153). The theocentric focus is also highlighted in recounting the rebuilding of the altar after God's homecoming to the temple had been described (Ezk 40:5-42:20; 43:13-27). This theocentric holiness has consequences for the purity of the land and the sanctification of its inhabitants. Leviticus' priestly worldview has been absorbed by the Zadokite priest Ezekiel in his prophecies.

One of the first things to notice, is that God's repossessing of his land as the real Owner, is correlated with the renewal of the life of the returnees, as expressed in Ezekiel 34-37 (Wright 2001:327-329; Zimmerli 1969:979). In a covenantal context, the indicative of grace is correlated with the imperative of a renewed life, inspired by a new heart

21.In Deuteronomy 28:43-44, Leviticus $25: 47$ is reconfigured: The advanced position of the immigrant is now understood as a covenant curse for the infidelity of the native born. In both texts, however, the immigrant's position is not determined by social immobility, but he could rather move upwards as the literary career of ObedEdom (from 2 Sam 6:1-12 to 2 Chr 25:24 via 1 Chr 13:13) shows.

22.In Ezekiel 40-48, the expression 'You will know that I am the Lord' is found 20 times (of the 54 times in Ezk 1-48). The expression 'for his own name's sake' is also indicative of the unmerited intervention of God in the history of (the remnant) of his people (Van Rooy 2018:133-136). See Joyce (2005:148) and Greenberg (1984:203-204) for the influence of P and HC on these issues in Ezekiel 40-48.
(Ezk 36:26-29). The creational renewal of the land, however, is not forgotten as the fruit of God's homecoming, as the reference to the 'covenant of peace' indicates (Ezk 34:25). The message of Ezekiel $47: 1-12^{23}$ is connected to this covenant, which comprises the Noahic covenantal teaching in Genesis 9:1, 8-11 (Batto 1987; Wielenga 1996:459-463). Ezekiel's vision has decidedly cosmic dimensions, as is not unusual in (proto-) apocalyptic eschatological prophecies ( $\mathrm{Hg}$ 2:6-9, 20-23; Zch 14:8-11; Ml 3:20; English Version [EV] 4:2). It is in this eschatologically reconfigured land of the future, that the immigrant would receive from its divine Owner, land tenure equal to that of the native-born, which could not be taken away from him.

This vision does not focus on the imminent future in postexilic Yehud after the first return home from exile in 539 BCE. Ezekiel 38-39, a deliberate editorial insertion between Ezekiel 33-37 and 40-48, clearly shows that in Ezekiel 40-48, the ultimate eschatological future is in view. ${ }^{24}$ After the return home, the returnees would live in peace and prosperity (Ezk 38:7-14); but 'after many days' (an eschatological time indicator) the mythical Gog from Magog, commanding the imaginary enemy from the North, will come to bring death and destruction to God's people. It would be God who would bring Gog upon his people, but he would also be the One to completely wipe out the enemy. Because God could not display his glory among the nations and his people (Ezk 39:21-23) in a land polluted by corpses, he left the cleansing of the land to his people (Ezk 38:14-23; 39:12-16) in the aftermath of the battle. The message for exiled Israel in the present (573 BCE) (see Ezk 40:1) was that, in the eschatological future, there would be ultimate peace, protected by God (Cook 1995:97-103; 2003:98-99; Wright 2001:316-317), who, faithful to the redemptive past, remembered the fortunes of Jacob (Ezk 39:25) in accordance with the promises in Ezekiel 37:24-28 (Block 1995:172-182). ${ }^{25}$

The imminent future of the returned exiles is addressed in Ezekiel 39:25-29 (Block 1987:266; Cook 1995:117-120; Wright 2001:322-324). The message of the ultimate removal of the threat of the North in Ezekiel 38-39 and subsequent peace in Ezekiel 40-48, should re-energise their faith and trust in God to fulfil in his compassion, his ancient promises to Jacob after their return home to the promised land (Ezk 39:25). This promise is in a covenantal context related to the remorse and repentance of the people (Ezk 43:10; 45:29), prompted by seeing the beauty of temple, city and land in this God-given vision (Zimmerli 1969:1082; Wright 2001:338). Back in the land of their ancestors, the people should live expectantly,

23.The river, flowing from the temple towards the Dead Sea, represents God's power to recreate the earth, focusing on the cancelling of the covenant curse in Leviticus 26:42. Zimmerli (1969:1192) refers to Genesis 2:10-14.

24.For the discussion about prophetic and apocalyptic eschatology in the Old Testament, see Gowan (2000), Grabbe and Haak (2003), Arnold (2007:23-39), and Wielenga (2016). The transition from the one to the other form of eschatology is fluent, as can be inferred from Ezekiel 38-39 as more proto-apocalyptic and in (2001:317-324) about the proto-apocalyptic nature of Ezekiel 38-39.

25.The introduction of divine judgement on the Day of the Lord (Wielenga 2018:2-5) in postexilic eschatological prophecy, has been prepared by Ezekiel 38-39. Pre-exilic Day of the Lord traditions are not included in this investigation. For the significance of the redemptive past in eschatological prophecy, see Wielenga (2015:4-7). 
awaiting the ultimate future beyond judgement as eschatologically portrayed in Ezekiel 40-48. In this inbetween time, their lives should reflect the glory of God whose incomparable holiness would also become known among the nations (Ezk 39:27-28), but first among the returned exiles in the reconstructed temple $(\mathrm{Hg} 2: 4-5)$.

The immigrant, mentioned in Ezekiel 47:22-23, formed part of this eschatological future. He would receive his own place among the tribes of Israel in their inheritance, just like the native-born. He should be fully accepted presently, because once he would be fully integrated into the renewed community of Israel's tribes. The treatment of the immigrant in postexilic Yehud during the in-between time, had to anticipate the one he would receive in the ultimate future. In this waiting time, God's holiness should be reflected in treating the immigrant as set out in Leviticus 19:33-34. In the priestly structured worldview of Ezekiel, the focus on God's holiness is never discussed without paying attention to the ethical purity of his people in 'his land' in which the immigrant one day would receive a portion equal to that of the native-born. This full integration is perceived as an eschatological event that should be anticipated in the present according to the Law of Moses.

The prophecies from Haggai to Malachi show that Ezekiel's vision did have an impact on the postexilic eschatological discourse (Ezk 40:4; Hg 1-2; Zch 14; Ml 3). This did not mean, however, that the anticipated future already shaped the social realities in Yehud post-539 BCE as it should have done according to the Law of Moses in HC and DC.

\section{The immigrant during the in-between time (MI 3:5)}

This eschatological worldview elucidated in Ezekiel 38-48, is also found in a postexilic prophet like Haggai (Kasher 2009:575-582; Wielenga 2015). Thematic correspondence between both prophets is evident as far as the theocentric eschatology with its cosmic dimensions is concerned. As part of the Book of the Twelve Prophets (Boda 2007:113-131; Nogalski 2007:125-136), ${ }^{26}$ synchronical links can be expected between Haggai and someone like Malachi (Wielenga 2016:3), sharing a common worldview and living in the same socio-political dispensation as well. The influence of Ezekiel's visionary prophecy can be recognised in Malachi, be it mediated through Haggai. Only, in Malachi the complaint was that the promised future had not arrived ( $\mathrm{Ml}$ 2:17). The people's hope had died, and the eschatological future did not shape life in Yehud in the present.

In the next two paragraphs, firstly the decline in eschatological expectation will be described as background for the illtreatment of the immigrant in postexilic Yehud; secondly, the ill-treatment of the immigrant, as stated in Malachi 3:5, will

26. Beuken (2018:143-150) argues from the position of the Book of Hosea, as the first of the minor prophets right after the Book of Ezekiel in the canon of prophetic books of the OT, that an intertextual connection between them could be examined. See also Ganzel $(2011: 13,16)$ about the thematic connections between Ezekiel and See also Ganzel (2011: be analysed in the context of Malachi's call to remember the law of Moses in the in-between time, created by the delay of the Day of the Lord (Ml 3:22, EV 4:6).

\section{The decline in eschatological hope}

The root cause of the spiritual crisis, addressed in Malachi, is the failure to live up to the theocentric teachings of Ezekiel and Haggai. It already started right after the return from exile in 539 BCE (Wielenga 2015:2-5). It was not the temple that was built first, but rather the altar (contra Ezk 43:1-12, 13-27). Therefore, the rebuilding of the temple was the focus of Haggai's prophetic ministry from 520 BCE onwards. According to Ezekiel's vision, this temple, insignificantly small as it was ( $\mathrm{Hg} 2: 3)$, would become the epicentre of the cosmic shake-up of creation and of the redrawing of the geo-political world map by the Lord Almighty. This would occur on the eschatological Day of the Lord $(\mathrm{Hg}$ 2:6-9, 21-22), establishing his Name among the nations, and subsequently peace on earth forever. As sign of things to come, the land would begin to heal ( $\mathrm{Hg} 2: 19 ; \mathrm{Zch} 8: 12)$. This Ezekielian vision should motivate the dejected people to continue the temple-building process in anticipation of the promised future.

The prophets, following Haggai in the Book of the Twelve, ${ }^{27}$ cherish the same eschatological hope (Zch 8:20-23;14:8-21; Ml 3:20-24), but in changed circumstances. In Ezekiel's vision, the temple and its ministries take central stage (Ml 1:6-2:9; 3:2-4). Only since the completion of the temple rebuilding in $516 \mathrm{BCE}$, they played an insignificant role in the life of the people. The eschatological fervour re-ignited by Haggai, was quenched. Malachi deals extensively with the cause of this spiritual crisis and puts the blame squarely on the temple staff and its failed ministry of teaching the Law of Moses (Zch 3:1-3; 7:5-6; Ml 1:6-2:9). In the terms of Ezekiel's vision (Ezk 47:1-12), from the centre of the land, the temple, not holiness but impurity emerges, polluting the land and desecrating its inhabitants. In this context, Malachi pronounces judgement on the Day of the Lord either as a refiner's fire for the repentant minority (Ml 3:2-4, 16-18), or as a burning furnace, leaving nothing but ash, for the unrepentant majority (Ml 3:19-21, EV 4:1-3). The future promised in Ezekiel 40-48 is still open, but now beyond judgement for a remnant only. The immigrant appears in Malachi 3:5 (and Zechariah 7:10) on the scene during this spiritual decline in the eschatological expectations in Yehud from around 539-460 BCE. ${ }^{28}$

\section{The immigrant in Malachi 3:5}

Two perspectives on the position of the immigrant in Malachi's time are developed in the following section. Firstly, in the context of Malachi 2:17-3:7a, the judgement announced (Ml 3:1b) is deferred, granting a time of grace for the ministry

27.For Joel, see Wielenga (2018:2-3) with literature references. Also 3 Isaiah (56-66) plays a role in this time period, see Wielenga (2016:4-5)

28.For Zechariah 7:7-10, see Boda (2017:31-50) and Beuken (1967:119-138). For Malachi 3:5, see Snyman (2015:128-142; 2018:159-166). 
of the messenger of Malachi 3:1a to be completed, affecting the treatment of the immigrant as well. Secondly, in the context of Malachi 3:22-24, EV 4:4-6, the awaiting of the arrival of the Lord (Ml 3:1b; 3:20-21) during the in-between time should be done in compliance with the Law of Moses (Wielenga 2018, 2019), likewise affecting the treatment of the immigrant.

\section{The ministry of the messenger ${ }^{29}$}

The delay of judgement on the Day of the Lord is an intrinsic component of the Old Testament teaching on eschatology (Hays 2016) that explains the two-sided perspective on the deferral: on the one hand, it is caused by the covenant-breaking behaviour of the people (Ml 1:6-2:9; $2: 10-14 ; 3: 5 ; 3: 6-8)$, but on the other hand, it is granted as a time of grace by a faithful God (Ml 1:2-5), for the messenger to complete his prophetic ministry. These two sides are kept together in prophetic eschatology in covenantal tension (Wielenga 2018:3, 5). ${ }^{30}$

In Malachi 2:17-3:7a, the 'sudden' and therefore incalculable arrival of the Lord to his temple to sit in judgement, will be preceded by God's messenger, identified as the prophet Elijah, preparing his way to come in the editorial addition to the book in Malachi 3:23, EV 4:5 (Wielenga 2018:3-6). The three great offenses to be judged are the failings of the temple staff and the men's maltreatment of women (Wielenga 2019:5-8), but withholding the tithes from God is not a less indictable offense $\left(\mathrm{Ml} \mathrm{3:6-8)} \cdot{ }^{31}\right.$ These transgressions of the Decalogue, the covenantal constitution of the nation (Dt 10:1, 5; 31:9-13) listed by Malachi, evoked the wrath of God. The prophetic ministry of the messenger, however, needs time to be completed and causes judgement to be postponed, creating space for a remorseful return to God and for the repudiation of the evils mentioned. In that case, judgement as a refiner's fire would not be God's final word, and the sun of righteousness with healing in its wings, would rise above the earth (Ml 3:20, EV 4:2; Ezk 47:1-12).

This should have beneficial effects for the immigrant, bracketed together, according to DC, with defrauded day labourers, widows and orphans. Together with other socially vulnerable classes (see also Neh 5:1-5), the immigrant was exploited in this era of spiritual decay and of dashed eschatological hope. A lack of fear for God was the hallmark of the spiritual character of the most of God's people (Ml 3:13-15). The Lord who comes in judgement, will take up the cause of the immigrant according to the teachings of DC, and confirmed by the eschatological vision in Ezekiel 47:22-23. Rhetorically the reference to the illtreated immigrant in Malachi 3:5, is intended to open the eyes of the people for the injustice done to him, but also for the judgement, delayed but

29. See Wielenga $(2016: 6-7)$ for a discussion about the identity of the messenger and his ministry.

30.The concept of 'dual causality' (Sonnet 2016:73-74) refers to the same sort of tension. In this article it is reused in a covenantal context.

31.Robbing God of the tithes due to Him also affects the immigrant who had a right to receive a part of it. not abrogated, waiting for them on the Day of the Lord (Ml 3:20, EV 4:1).

\section{Compliance with the Law of Moses}

Anticipating the future to be ushered in at the coming Day of the Lord, when the immigrant will be made co-heir of the land with the native-born, the Law of Moses should inform Israel's treatment of the immigrant in the present time (Ml 3:22, EV 4:6).32 DC especially should shape the people's behaviour towards the immigrant in the in-between time- a behaviour anchored in the redemptive past (the Egyptexperience) and shaped by the anticipated future. The preaching of the Day of the Lord in Malachi is double-edged: positively to avert judgement executed on it, and negatively to impress upon the people the serious consequences of indifference to the prophetic exhortation.

However, fear for judgement should not be the driving force behind the change in their attitude and behaviour towards the immigrant. Covenantal faithfulness and righteousness should motivate them (Lv 19:33-34: Dt 27:19; 28:43-44). Rhetorically, the emphasis on divine judgement on the Day of the Lord serves to motivate the people not to exclude the immigrant from justice, but on the contrary, to include him in accordance with the instructions in DC (Wielenga 2018:7-8). Awaiting the eschatological future with confidence cannot be done without justice for the immigrant. That this requires the permanent teaching ministry in the Law of Moses at home and in the temple, can be inferred from the expression to 'remember'33 this Law (Wielenga 2019:2-3). The warning against 'forgetting' the Law of Moses (Dt 4:9; 8:11, 14), includes the instructions about the treatment of the immigrant.

\section{Conclusion}

The appearance of the immigrant in the postexilic text of Malachi 3:5, can be explained against the background of Ezekiel 47:22-23 where the immigrant emerges in an eschatological context as well. Both prophetic pronouncements are informed by the Law of Moses on the status of the immigrant in Israel in the past, present and future of salvation history. Ezekiel, however, has been mainly influenced by HC and Malachi by DC.

The two 'law codes' are not in conflict with one another, but in complementary harmony. They were received, certainly in post-exilic times, as part of the authoritative Law of Moses, which had to be remembered and therefore taught in the temple ministry and at home. The Law of Moses, the servant

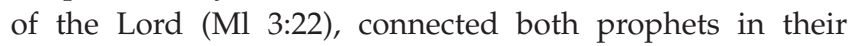
specific teachings on the position of the immigrant. Ezekiel

32.The covenantal character of Malachi's theology is generally classified as Deuteronomic; see Wielenga (2016:2, 2019:3-4) with literature references. In Malachi 3:22, the Law of Moses does not exclusively refer to DC, but it has been one of its main influences in Malachi. The expression, 'remember' the Law of Moses in Malachi 3:22, appears in Deuteronomy 4-11 (6:7, 9; 11:19) and 27-32
$(31: 9-13)$.

33.Memory has a 'transformative quality' (Hwang 2013:146), motivating to observance of the Law of Moses. See also Ellman's (2011) thorough analysis of the function of memory in Deuteronomic and Priestly traditions. 
influenced Malachi through Haggai. Because the immigrant would have an integrated status in the eschatological future, he should also have one in the present time, based upon God's redemptive actions (the Egypt-experience) in the past.

Lastly, the significance of biblical eschatology for a fair treatment of the immigrant in the present time, should not be underestimated. The relevant prophecies of Ezekiel and Malachi too should inform the teaching and praxis of Christian communities of faith the world over, to stimulate and guide their approach towards the immigrant.

\section{Acknowledgement}

The present author wants to thank Mrs Hester Lombard and her staff at North-West University Library (Potchefstroom) for their invaluable support for his research for this and previous articles.

\section{Competing interest}

The author has declared that no competing interest exists.

\section{Author's contributions}

I declare that I am the sole author of this research article.

\section{Ethical consideration}

This article followed all ethical standards for carrying out research without direct contact with human or animal subjects.

\section{Funding information}

This research received no specific grant from any funding agency in the public, commercial or not-for-profit sectors.

\section{Data availability statement}

Data sharing is not applicable to this article as no new data were created or analysed in this study.

\section{Disclaimer}

The views and opinions expressed in this article are those of the author and do not necessarily reflect the official policy or position of any affiliated agency of the author.

\section{References}

Adamo, D., 2019, 'Ebed-Melech's protest to king Zedekiah as model of modern protes movement (Jeremiah 38:1-17)', In die Skriflig / In Luce Verbi 53(1), a2450. https:// doi.org/10.4102/ids.v53i1.2450

Arnold, B.T., 2007, 'Old Testament eschatology and the rise of apocalypticism', in J. Walls (ed.), The Oxford Handbook of Eschatology, pp. 23-39, Oxford University Press, Oxford.

Arnold, B.T., 2011, 'The love and fear antinomy in Deuteronomy 5-11', Vetus Testamentum 61(4), 551-569. https://doi.org/10.1163/156853311X560754

Arnold, B.T., 2014, 'Deuteronomy 12 and the law of the central sanctuary noch einmal', Vetus Testamentum 64(2), 236-248. https://doi.org/10.1163/1568533012341150

Arnold, B.T., 2016, 'Israelite worship as envisioned and prescribed in Deuteronomy 12 ', Zeitschrift für Altorientalische und Biblische Rechtsgeschichte 22, 161-176.
Arnold, B.T., 2017, 'The book of Deuteronomy: Pseudepigraphy, pseudonymity, or something else altogether?', in D.I. Block \& R.L. Schultz (eds.), Sepher Torath Mosheh Studies in the composition and interpretation of Deuteronomy, pp. 139-160, Studies in the composition and interpr
Hendrickson Publishers, Peabody, MA.

Awabdy, M.A., 2011, 'Green eggs and Shawarma: Reinterpretation of the Bible, reforming mission with Leviticus' gēr as a test case', The Ashbury Journal 66(1), 31-45.

Awabdy, M.A., 2012, “"He loves the immigrant”: Deuteronomy's theological and socia vision for the gêr', PhD thesis, Ashbury Theological College, Wilmore, KY

Batto, B.F., 1987, 'The covenant of peace: A neglected Near Eastern motif', Catholic Biblical Quarterly 49(2), 187-211.

Bergsma, J.S., 2015, 'Ezekiel, the Pentateuch, and the Samaritans: Converging lines of scholarship highlighting the absence of Zion from the Pentateuch', paper delivered at Midwest Regional Society of Biblical Literature, Bourbonnais, III.

Beuken, W.A.M., 1967, Haggai-Sacharja 1-8, Van Gorcum, Assen. (Studien zur Überlieferungsgeschichte der Frühnachexilischen Prophetie).

Beuken, W.A.M., 2018, 'It takes two prophets to fathom the God of Israel: Ezekiel 36-48 as a porch to Hosea 1-2', in J. Dekker \& G. Kwakkel (eds.), Reading and listening: Meeting one God in may texts, (Festschrift for Eric Peels), Amsterdamse Cahiers supplement series 16, pp. 143-150, Uitgeverij 2VM, Bergambacht.

Block, D.I., 1987, 'Gog and the pouring out of the spirit: Reflections on Ezekiel 39:21-29', Vetus Testamentum 37(3), 257-270. https://doi.org/10.2307/1517628

Block, D.I., 1995, 'Bringing back David: Ezekiel's messianic hope', in P.E. Sattherthwaite, R.S. Hess \& G.J. Wenham (eds.), The Lord's anointed: Interpretation of Old Testament messianic texts, pp. 167-188, Paternoster Press, Carlisle.

Boda, M.J., 2007, 'Messengers of hope in Haggai-Malachi', Journal for the Study of the Old Testament 32(1), 113-131. https://doi.org/10.1177/0309089207083768

Boda, M.J., 2017, 'From fasts to feasts: The literary function of Zechariah 7-8', in M.J. Boda (ed.), Exploring Zechariah, Volume 1: The development of Zechariah and its role within the Twelve, pp. 31-50, SBL Press, Atlanta, GA. (Ancient Near Eastern Monographs 17).

Bosman, H.L., 2018, 'Loving the neighbor and the resident alien in Leviticus 19 as ethical redefinition of holiness', Old Testament Essays 31(3), 571-590. https://doi. ethical redefinition of holiness', Old Testament
org/10.17159/2312-3621/2018/v31n3a10

Braulik, G., 2012, 'Die Liebe Gottes zwischen Gott und Israel: Zur theologische Mitte des Buches Deuteronomium', Internationale katholische Zeitschrift 41, 549-564.

Brett, M.G., 1996, 'Interpreting ethnicity: Method, hermeneutics, ethics', in M.G. Brett (ed.), Ethnicity and the Bible, pp. 3-22, Brill, Leiden. (Biblical Interpretation Series 19).

Burnside, J.P., 2001, The status and welfare of immigrants: The place of the foreigner in biblical law and its relevance to contemporary society, The Jubilee Centre, Cambridge.

Carroll, M.D., 2013, 'Welcoming the stranger: Towards a theology of immigration in Deuteronomy', in J.S. DeRouchie, J. Gile \& K.J. Turner (eds.), For our good always: Deuteronomy', in J.S. DeRouchie, J. Gile \& K.J. Turner (eds.), For our good always: Studies on the message and influence of Deuter
pp. 441-461, Eisenbrauns, Winona Lake, IN.

Cook, S.L., 1995, Prophecy and apocalypticism: The postexilic social setting, Fortress Press, Minneapolis, MN.

Cook, S.L., 2003, The apocalyptic literature, Abingdon Press, Nashville, TN.

Cook, S.L., 2013, 'God's real absence and real presence in Deuteronomy and Deuteronomism', in N. McDonald \& I.J. de Hulster (eds.), Divine presence and absence in exile and postexlic Judaism, pp. 121-143, Mohr Siebeck, Túbingen. (Forschungen zur Alten Testaments 61).

Cook, S.L., 2015, Reading Deuteronomy: A literary and theological commentary, Smyth \& Helwys Publishing, Macon, GA.

Ellman, B., 2011, Memory and religious praxis: The meaning and function of memory in Deuteronomic and Priestly religion, PhD Thesis, Jewish Theological Seminary, New York, NY.

Friedl, A., 2016, 'The reception of the deuteronomic social law in the Primitive Church of Jerusalem according to the book of Acts', Acta Theologica suppl. ser. 23 176-200. https://doi.org/10.4314/actat.v23i1s.9

Ganzel, T., 2011, 'The shattered dream: The prophecies of Joel: A bridge between Ezekiel and Haggai?', Journal of Hebrew Scriptures 11(6), 1-21. https://doi. org/10.5508/jhs.2011.v11.a6

Ganzel, T. \& Holtz, S. 2014, 'Ezekiel's temple in Babylonian context', Vetus Testamentum 64(2), 211-226. https://doi.org/10.1163/15685330-12341148

Gile, J., 2013, 'Deuteronomy and Ezekiel's theology of exile', in J.S. DeRouchie, J. Gile \& K.J. Turner (eds.), For our good always: Studies on the message and influence of Deuteronomy in honor of Daniel I. Block, pp. 287-306, Eisenbrauns, Winona Lake, IN.

Gowan, D.E., 1987, 'Wealth and poverty in the Old Testament: The case of the widow, the orphan and the sojourner', Interpretation 41(4), 341-353. https://doi. org $/ 10.1177 / 002096438704100402$

Gowan, D.E., 2000, Eschatology in the Old Testament, 2nd edn., Clark, Edinburgh.

Grabbe, LL. \& R.D, Haak (eds.), 2003, Knowing the end from the beginning: The prophetic, the apocalyptic and their relationship, Clark International, London.

Greenberg, M., 1984, 'The design and themes of Ezekiel's restoration program' Interpretation 38(2), 181-208. https://doi.org/10.1177/002096438403800206

Halpern, B., 2013, 'Between elective autocracy and democracy: Formalizing biblical constitutional theory', in D.S. Vanderhooft \& A. Winitzer (eds.), Literature as politics, politics as literature:Essays on the Ancient Near East in honor of $P$ Machinist, pp. 165-183, Eisenbrauns, Winona Lake, IN.

Hartshorn, L., 2010, Strangers in a strange land: Exile, immigration, survival, and identity, Peace and Justice Support Network of the Mennonite Church
USA, viewed 23 July 2019, from http://peace.mennolink.org/articles/strangerland. USA, view 
Hays, C.M. (ed.), 2016, When the Son of Man didn't come: A constructive proposal on the Delay of the Parousia, Fortress Press, Minneapolis, MN.

Heller, R.J. 2007, 'The widow in Deuteronomy: Beneficiary of compassion and cooption', in C.J. Roetzel \& R.L. Forster (eds.), The impartial God: Essays in biblical studies in honor of Jouette M. Bassler, pp. 1-11, Sheffield Phoenix Press, Sheffield.

Hieke, T., 2015, 'The covenant in Leviticus 26: A concept of admonition and redemption', in R.J. Bautch \& G.N. Knoppers (eds.), Covenant in the Persian period: From Genesis to Chronicles, pp. 75-92, Eisenbrauns, Winona Lake, IN.

Hwang, J., 2013, 'The rhetoric of theophany: The imaginative depiction of Horeb in Deuteronomy 9-10', in J.S. DeRouchie, J. Gile \& K.J. Turner (eds.), For our good always: Studies in the message and influence of Deuteronomy in honor of Daniel I. Block, pp. 145-164, Eisenbrauns, Winona Lake, IN.

Jokiranta, J., 2014, 'Conceptualizing gēr in the Dead Sea Scrolls', in K. de Troyer, T.M. Law \& M. Liljeström (eds.), In the footsteps of Sherlock Holmes: Studies in the Biblical text in honor of Anneli Aljmelaeus, pp. 659-677, Peeters Publishing, Leuven.

Joosten, J., 1996, People and land in the Holiness Code: An exegetical study of the ideational framework of the Law in Leviticus 17-26, Brill, Leiden. (Supplementum Vetus Testamentum 67).

Joyce, P.M., 2005, 'Temple and worship in Ezekiel 40-48', in J. Day (ed.), Temple and worship in biblical Israel, pp. 145-163, Clark, London.

Kasher, R., 2009, 'Haggai and Ezekiel: The complicated relations between the two prophets', Vetus Testamentum 59(4), 556-582. https://doi.org/10.1163/156853309X445016

Le Roux, J.H., 1987, 'Teologie in 'n krisis', in F.E. Deist \& J.H. le Roux (eds.), Rewolusie en reïnterpretasie, pp. 101-159, Tafelberg-Uitgewers, Kaapstad. (Die literatuur van die Ou Testament, deel 4).

McConville, J.G., 2002, Deuteronomy, IVP Academic, Downers Grove, IL. (Apollos Old Testament Commentary 5).

Na'adav, N., 2008, 'Sojourners and Levites in the kingdom of Judah in the seventh century BCE', Zeitschrift für Altorientalische und Biblische Rechtsgeschichte 14, 237-279.

Nogalski, J.D., 2007, 'Recurring themes in the book of the Twelve: Creating points of contact for a theological reading', Interpretation 61(2), 125-136. https://doi. org/10.1177/002096430706100202

Onishi, Y., 2017, 'Remember the foreigner: The gēr in Pentateuchal law', MTh thesis, University of the Free State, viewed 25 May 2019, from https://scholar.ufs.ac.za/ xmlui/handle/11660/9209.

Oommen, J.K., 1997, Citizenship, nationality and ethnicity: Reconciling competing identities, Polity Press, Cambridge.

Rom-Shiloni, D., 2005, 'Ezekiel as the voice of the exiles and constructor of exile ideology', Hebrew Union College Annal 76, 1-45.

Schniedewind, W.M., 2015, 'Scripturalization in ancient Judah', in B.B. Schmidt (ed.), Contextualizing Israel's sacred writings, pp. 305-321, BL Press, Atlanta, GA.

Schwartz, B.J. 2009, 'Introduction: The strata of the priestly writings and the revisited relative dating of $\mathrm{P}$ and $\mathrm{H}^{\prime}$, in $\mathrm{S}$. Shectman \& J.S. Baden (eds.), The strata of the
priestly writings: Contemporary debate and future direction, pp. 1-12, priestly writings: Contempor
Theologische Verlag, Zúrich.

Smith-Christopher, D.L., 1996, 'Between Ezra and Isaiah: Exclusion, transformation and inclusion of the foreigner in post-exilic biblical theology', in M.G. Brett (ed.), Ethnicity and the Bible, pp. 117-142, Brill, Leiden. (Biblical Interpretation Series 19).

Snyman, S.D., 2015, Malachi, Peeters, Leuven. (Historical Commentary on the Old Testament)
Snyman, S.D., 2018, "'Where is the God of justice?" Listening and hearing in the Word of God in Malachi 2:17-3:7a', in J. Dekker \& G. Kwakkel (eds.), Reading and listening: Meeting one God in many texts, pp. 159-168, Uitgeverij 2VM, Bergambacht. (Amsterdamse Cahiers supplement series 16).

Sonnet, J-P., 2016, 'The siege of Jerusalem between rhetorical maximalism (Deuteronomy 28) and narrative Minimalism (2 Kings 25)', in P. Dubovský, D. Markl \& J-P. Sonnet (eds.), The fall of Jerusalem and the rise of Torah, pp. 73-88, Mohr Siebeck, Tübingen.

Tidball, D., 2005, The message of Leviticus, InterVarsity Press, Leicester. (The Bible Speaks Today).

Van Houten, C., 1992, 'Remember that you were aliens: A tradition-historical study', in E. Ulrich, J.W. Wright, R.P. Carroll \& P.R. Davies (eds.), Essays on the formation and heritage of Second Temple Judaism, pp. 224-240, JSOT Press, Sheffield. (JSOT SS 149).

Van Rooy, H.F., 2018, 'Seeing, listening and speaking: Encountering the glory of the Lord in the book of Ezekiel', in J. Dekker \& G. Kwakkel (eds.), Reading and listening: Meeting one God in many texts, pp. 135-143, Uitgeverij 2VM, Bergambacht. (Amsterdamse Cahiers supplementum series 16).

Vogt, P., 2003, 'Religious concepts in the theology of Deuteronomium: A reappraisal of the Deuteronomic theology and the significance of Torah', PhD thesis, Gloucestershire University, Cheltenham.

Wielenga, B., 1994, 'Zendingshermeneutiek: Een inleiding', in J. Bouma (red.), Begeleidend schrijven. 25 jaar Theologische Studiebegeleiding, pp. 224-235, Buyten \& Schipperheyn, Amsterdam.

Wielenga, B., 1996, 'Over het noachitische verbond als vredesverbond: Pactum Salutis in Vetere Testamento', In die Skriflig 30(4), 457-470. https://doi.org/10.4102/ids. v30i4.1589

Wielenga, B., 2013, 'Renewal and reconstruction: Holy Writ in Ezra-Nehemiah - A missional reading', In die Skriflig/In Luce Verbi 47(1), a72. https://doi.org/104102/ ids.v47i1.72

Wielenga, B., 2015, 'Eschatological hope in Haggai: A homiletic reading', In die Skriflig / In Luce Verbi 49(1), a1820. https://doi.org/10.4102/ids.v49i11820

Wielenga, B., 2016, 'Eschatology in Malachi: The emergence of a doctrine', In die Skriflig / In Luce Verbi 50(1), a2091. https://doi.org/104102/ids.v50i1.2091

Wielenga, B., 2018, 'The delay of the Day of the Lord in Malachi: A missional reading', In die Skriflig / In Luce Verbi 52(1), a2362. https:/doi.org/10.4102/ids. reading,
v52i1.2362

Wielenga, B., 2019, 'Remember the Law of Moses: Malachi 3:22 in prophetic eschatology, with a missional postscript', In die Skriflig / In Luce Verbi 53(1), a2452. https://doi.org./10.4102/ids.v53i12452

Wright, C.H.J., 2001, The message of Ezekiel, InterVarsity Press, Leicester. (The Bible Speaks Today).

Wright, C.H.J., 2006, The mission of God: Unlocking the Bible's grand narrative, IVP Academic, Downers Grove, IL.

Wünsch, H-G., 2014, 'The stranger in God's land - Foreigner, stranger, guest: What can we learn from Israel's attitude towards strangers?', Old Testament Essays 27(3), we learn from $1129-1154$.

Zehnder, M., 2017, 'Literary and other observations on passages dealing with foreigners in the book of Deuteronomy: The command to love the gerr read in context', in D.I. Block \& R.L. Schultz (eds.), Sepher Torath Mosheh: Studies in the composition and interpretation of Deuteronomy, pp. 192-231, Hendrickson, Peabody, MA.

Zimmerli, W., 1969, Ezechiel, 2. Teilband (Ezechiel 25-48), Neukirchener Verlag, Neukirchen-Vluyn. (Biblischer Kommentar Altes Testament, 13/2). 